\title{
Desorption isotherms and isosteric heat of 'cajuzinho-do-cerrado' achenes
}

\author{
Karine F. Barbosa ${ }^{1}$, Juliana de F. Sales ${ }^{1}$, Osvaldo Resende ${ }^{1}$, \\ Daniel E. C. de Oliveira ${ }^{2}$, Jacson Zuchi ${ }^{3} \&$ Kelly A. de Sousa ${ }^{1}$ \\ ${ }^{1}$ Instituto Federal Goiano. Rio Verde, GO. E-mail: karinefebarbosa@gmail.com (Corresponding author); julianacefetrv@yahoo.com.br; \\ osvresende@yahoo.com.br; kellyapsousa@yahoo.com.br \\ ${ }^{2}$ Instituto Federal Goiano. Iporá, GO. E-mail: oliveira.d.e.c@gmail.com \\ ${ }^{3}$ Instituto Federal do Mato Grosso. Campo Novo do Parecis, MT. E-mail: jacson.zuchi@ifgoiano.edu.br
}

\section{Key words:}

Anacardium humile St. Hil.

hygroscopicity

water activity

\begin{abstract}
A B S T R A C T
The objective of this study was to determine the desorption isotherms of 'cajuzinho-docerrado' achenes (Anacardium humile St. Hil.) in various conditions of temperature and water activity, as well as to select the one that best represents the phenomenon and to determine the isosteric heat of desorption. The fruits were collected at the Emas National Park, in the municipality of Mineiros-GO, Brazil, pulped and then subjected to drying in silica gel at temperature of $25 \pm 2{ }^{\circ} \mathrm{C}$ until the moisture contents of $17.6,13.6,11.1,8.7$ and 5.3 (d.b.\%). After drying, the desorption isotherms were determined by the indirect static method. The water activity (Aw) was determined at different temperatures, and the achenes were placed in a B.O.D. chamber, regulated at $10,20,30$ and $40^{\circ} \mathrm{C}$. Data of hygroscopic equilibrium moisture content were fitted to different mathematical models through nonlinear regression analysis, using the Gauss-Newton method. The Copace model was the one that best represented the hygroscopicity of 'cajuzinho-do-cerrado' achenes, while the integral isosteric heat of desorption of 'cajuzinho-do-cerrado' achenes for the moisture content range of 4.51 to 13.40 (\% d.b.) varied from $2,734.82$ to $2,548.49 \mathrm{~kJ} \mathrm{~kg}^{-1}$.
\end{abstract}

\section{Palavras-chave:}

Anacardium humile St. Hil.

higroscopicidade

atividade de água

\section{Isotermas de dessorção e calor isostérico de aquênios de cajuzinho-do-cerrado}

\section{R E S U M O}

Objetivou-se, com este trabalho, determinar as isotermas de dessorção de aquênios de cajuzinho-do-cerrado (Anacardium humile St. Hil.) em diversas condições de temperatura e atividades de água e selecionar aquela que melhor representa o fenômeno e determinar o calor isostérico de dessorção. Os frutos foram coletados no Parque Nacional das Emas, no município de Mineiros - GO, despolpados e em seguida submetidos à secagem em sílica gel a temperatura de $25 \pm 2{ }^{\circ} \mathrm{C}$, até atingirem os teores de água de 17,$6 ; 13,6 ; 11,1 ; 8,7 ; 5,3$ (\% b.s). Após a secagem foram determinadas as isotermas de dessorção pelo método estático indireto. A atividade de água $(\mathrm{Aw})$ foi determinada sob diferentes temperaturas sendo os aquênios acondicionados em câmara B.O.D., regulada a 10, 20, 30 e $40{ }^{\circ} \mathrm{C}$; aos dados de teor de água de equilíbrio foram ajustados a diferentes modelos matemáticos por meio da análise de regressão não linear, pelo método Gauss-Newton. O modelo Copace foi o que melhor representou a higroscopicidade dos aquênios de cajuzinho-do-cerrado enquanto os valores de calor isostérico integral de dessorção dos aquênios de cajuzinho-do-cerrado para a faixa de teor de água de 4,51 a 13,40 (\% b.s.) variaram de 2734,82 a $2548,49 \mathrm{~kJ} \mathrm{~kg}^{-1}$. 


\section{INTRODUCTION}

The storage of seeds constitutes an important strategy for ex-situ genetic conservation of vegetal species, achieving goals such as plant breeding or propagation. The conditions of relative air humidity and temperature during the storage and the seeds reaching the specific hygroscopic equilibrium will determine the maintenance of their physiological quality for longer or shorter time (Borges et al., 2009).

Hygroscopicity refers to the affinity to the water, i.e., the hydrophilous behavior of some substances in relation to the water. Thus, the chemical composition influences the water-sorption properties of the seeds (Marcos Filho, 2005). Isotherms are obtained through mathematical equations that correlate the moisture content of the product and the relative equilibrium moisture content as a function of a specific temperature (Corrêa et al., 2005b).

For obtaining sorption isotherms, it is essential the study on water activity, which describes the relationship between the amount of water sorbed by the product, the relative humidity and the temperature (Silva et al., 2007). The tendency of the product to absorb water from the environment determines its hygroscopicity, which is the fundamental quality parameter of agricultural products (Tocon et al., 2009).

Drying and storage of agricultural products require the study of the isosteric heat, which is essential to predict the amount of energy necessary for the drying process and also for the removal of water from the hygroscopic products (Lima et al., 2008). This study aimed to determine the desorption isotherms of achenes of 'cajuzinho-do-cerrado' (Anacardium humile St. Hil.), for various conditions of temperature and water activity, and fit different mathematical models to the experimental data, besides determining the desorption isosteric heat.

\section{Material AND Methods}

'Cajuzinho-do-cerrado' fruits were collected at the Emas National Park, located in the municipality of Mineiros-GO, Brazil ( $\left.18^{\circ} 6^{\prime} 23^{\prime \prime} \mathrm{S} ; 52^{\circ} 55^{\prime} 40^{\prime \prime} \mathrm{W} ; 820 \mathrm{~m}\right)$. Then, the fruits were taken to the Laboratory of Seeds of the Federal Institute of Education, Science and Technology of Goiás (IF Goiano) Campus of Rio Verde, and the voucher specimen was deposited in the herbarium of the Federal University of Goiás - Campus of Jataí.

The fruits were pulped and the achenes were separated with the aid of a nylon thread. After that, the achenes were washed for disinfection in a solution of sodium hypochlorite at $2 \%$ for $5 \mathrm{~min}$. The initial moisture content of the achenes (38.89\% d.b.) was determined after washing the fruits and the drying process was performed in silica gel, at temperature of $25 \pm 2{ }^{\circ} \mathrm{C}$, until the moisture contents of 13.6, 11.1, 8.7 and 5.3 (\% d.b.). The moisture content was determined by the method of the oven at $105 \pm 3{ }^{\circ} \mathrm{C}$, for $24 \mathrm{~h}$, according to the Rules for Analysis of Seeds - RAS (Brasil, 2009), in four replicates.

Desorption isotherms were determined by the indirect static method. Water activity (Aw) for each moisture content was determined using the device Hygropalm (Model Aw1) at the temperatures of $10,20,30$ and $40^{\circ} \mathrm{C}$, in a B.O.D. chamber, at the Laboratory of Post-Harvest of Vegetal Products of the IF Goiano, Campus of Rio Verde.

The experimental data of equilibrium moisture content were fitted to the mathematical models shown in the Eq. 1 to 12 , which are traditionally used to predict the hygroscopicity of vegetal products.

- Chung-Pfost

$$
\mathrm{Xe}=\mathrm{a}-\mathrm{b} \cdot \ln \left[-(\mathrm{T}+\mathrm{c}) \cdot \ln \left(\mathrm{a}_{\mathrm{w}}\right)\right]
$$

- Copace

$$
\mathrm{Xe}=\exp \left[\mathrm{a}-(\mathrm{b} \cdot \mathrm{T})+\left(\mathrm{c} \cdot \mathrm{a}_{\mathrm{w}}\right)\right]
$$

- GAB

$$
X e=\frac{\left(a \cdot b \cdot c \cdot a_{w}\right)}{\left[\left(1-c \cdot a_{w}\right) \cdot\left(1-c \cdot a_{w}+b \cdot c \cdot a_{w}\right)\right]}
$$

- Modified Halsey

$$
\mathrm{Xe}=\left[\frac{\exp (\mathrm{a}-\mathrm{b} \cdot \mathrm{T})}{-\ln \left(\mathrm{a}_{\mathrm{w}}\right)}\right]^{1 / \mathrm{c}}
$$

- Sabbah

$$
\mathrm{Xe}=\mathrm{a} \cdot\left(\mathrm{a}_{\mathrm{w}}^{\mathrm{b} / \mathrm{T}^{\mathrm{c}}}\right)
$$

- Sigma Copace

$$
\mathrm{Xe}=\exp \left\{\mathrm{a}-(\mathrm{b} \cdot \mathrm{T})+\left[\mathrm{c} \cdot \exp \left(\mathrm{a}_{\mathrm{w}}\right)\right]\right\}
$$

- Cavalcanti Mata

$$
X e=\left\{\frac{\ln \left(1-a_{w}\right)}{\left[a \cdot\left(T^{b}\right)\right]}\right\}^{1 / c}
$$

- Modified Henderson

$$
\mathrm{Xe}=\left\{\frac{\ln \left(1-\mathrm{a}_{\mathrm{w}}\right)}{[-\mathrm{a} \cdot(\mathrm{T}+\mathrm{b})]}\right\}^{1 / \mathrm{c}}
$$

- Henderson

$$
\mathrm{Xe}=\left\{\frac{\ln \left(1-\mathrm{a}_{\mathrm{w}}\right)}{(-\mathrm{a} \cdot \mathrm{T}+237.16)}\right\}^{1 / \mathrm{c}}
$$

- BET

$$
\mathrm{Xe}=\left\{1 /\left[\left(1-\mathrm{a}_{\mathrm{w}}\right) \cdot(1 / \mathrm{a} \cdot \mathrm{b}+((\mathrm{a}-1) / \mathrm{a} \cdot \mathrm{b}))\right]\right\}
$$


- Oswin

$$
\mathrm{Xe}=\frac{(\mathrm{a}+\mathrm{b} \cdot \mathrm{T})}{\left[\frac{\left(1-\mathrm{a}_{\mathrm{w}}\right)}{\mathrm{a}_{\mathrm{w}}}\right]^{1 / \mathrm{c}}}
$$

- Modified GAB

$$
\mathrm{Xe}=\left(\mathrm{a} \cdot \mathrm{b} \cdot \mathrm{a}_{\mathrm{w}}\right) \cdot \frac{(\mathrm{c} / \mathrm{T})}{\left[1-\mathrm{b} \cdot \mathrm{a}_{\mathrm{w}}+(\mathrm{c} / \mathrm{T}) \cdot \mathrm{b} \cdot \mathrm{a}_{\mathrm{w}}\right] \cdot\left(1-\mathrm{b} \cdot \mathrm{a}_{\mathrm{w}}\right)}
$$

where:

Xe - equilibrium moisture content, \% d.b.;

$\mathrm{a}_{\mathrm{w}}$ - water activity, decimal;

$\mathrm{T}$ - temperature, ${ }^{\circ} \mathrm{C}$; and,

a, b, c - coefficients that depend on the studied product.

For the fitting of the mathematical models, a non-linear regression analysis was performed through the GaussNewton method. The degree of fit of each model was based on the significance of the coefficients by the t-test, adopting a $5 \%$ significance level, the magnitude of the determination coefficient $\left(R^{2}\right)$, the values of the relative mean error $(P)$, estimated mean error (SE) and the Chi-square test $\left(\chi^{2}\right)$, in the confidence interval of $95 \%(\mathrm{P}<0.05)$. The value of the relative mean error, when lower than $10 \%$, was considered as one of the criteria for the selection of the models, according to Mohapatra \& Rao (2005). Relative and estimated mean errors and the Chi-square test for each one of the models were calculated according to Eqs. 13, 14 and 15, respectively:

$$
\begin{gathered}
\mathrm{P}=\frac{100}{\mathrm{n}} \sum \frac{|\mathrm{Y}-\hat{\mathrm{Y}}|}{\mathrm{Y}} \\
\mathrm{SE}=\sqrt{\frac{\sum(\mathrm{Y}-\hat{\mathrm{Y}})^{2}}{\mathrm{RDF}}} \\
\chi^{2}=\sum \frac{(\mathrm{Y}-\hat{\mathrm{Y}})^{2}}{\mathrm{RDF}}
\end{gathered}
$$

where:

Y - experimental value;

$\hat{Y} \quad$ - value estimated by the model;

$\mathrm{n}$ - number of experimental observations; and,

RDF - degrees of freedom of the model (number of observations minus the number of parameters of the model).

The net isosteric heat of sorption (or differential enthalpy) for each equilibrium moisture content was calculated through the Clausius-Clayperon equation (Iglesias \& Chirife, 1976), as shown in Eq. 16:

$$
\frac{\partial \operatorname{In}\left(\mathrm{a}_{\mathrm{w}}\right)}{\partial \mathrm{T}}=\frac{\Delta \mathrm{h}_{\mathrm{st}}}{\mathrm{RT}_{\mathrm{a}}^{2}}
$$

where:

$\mathrm{a}_{\mathrm{w}}$ - water activity, decimal;

$\mathrm{T}_{\mathrm{a}}^{\mathrm{w}}$ - absolute temperature, $\mathrm{K}$;

$\Delta \mathrm{h}_{\text {st }}$ - differential enthalpy, $\mathrm{kJ} \mathrm{kg}^{-1}$; and,

$\mathrm{R}$ - water vapor constant, $0.4619 \mathrm{~kJ} \mathrm{~kg}^{-1} \mathrm{~K}^{-1}$.

Integrating Eq. 16 and assuming that the net isosteric heat of sorption is independent of temperature, the net isosteric heat of sorption for each equilibrium moisture content is obtained according to Eq. 17 (Wang \& Brennan, 1991):

$$
\operatorname{In}\left(\mathrm{a}_{\mathrm{w}}\right)=\left(\frac{\Delta \mathrm{h}_{\mathrm{st}}}{\mathrm{R}}\right) \cdot \frac{1}{\mathrm{~T}_{\mathrm{a}}}+\mathrm{C}
$$

where:

C - coefficient of the model.

The integral isosteric heat of desorption was obtained by adding the value of latent heat of free water to the values of net isosteric heat of sorption, according to Eq. 18:

$$
\mathrm{Q}_{\mathrm{st}}=\Delta \mathrm{h}_{\mathrm{st}}+\mathrm{L}=\mathrm{a} \cdot \exp (-\mathrm{b} \cdot \mathrm{Xe})+\mathrm{L}
$$

where:

$\mathrm{Q}_{\mathrm{st}}$ - integral isosteric heat of sorption, $\mathrm{kJ} \mathrm{kg}^{-1}$; and,

$\mathrm{a}, \mathrm{b}$ and $\mathrm{c}$ - coefficients of the model.

The latent heat of vaporization of free water $(\mathrm{L})$, in $\mathrm{kJ} \mathrm{kg}^{-1}$, used in the calculation of $\mathrm{Q}_{\mathrm{st}}$, was obtained using the mean temperature $(\mathrm{T})$ of the studied range, in ${ }^{\circ} \mathrm{C}$, according to the following equation:

$$
\mathrm{L}=2502.2-2.39 \cdot \mathrm{T}
$$

where:

$\mathrm{L} \quad$ - latent heat of vaporization of free water, $\mathrm{kJ} \mathrm{kg}^{-1}$.

\section{Results AND Discussion}

The mean values of equilibrium moisture content obtained as a function of temperature and water activity are shown in Table 1. For a certain temperature, the equilibrium moisture content increases with the increment in water activity for 'cajuzinho-do-cerrado' achenes. Similar result was observed by Costa et al. (2013) in fruits of Crambe abyssinica (crambe), and this species is an oilseed plant, like 'cajuzinho-do-cerrado'.

Table 2 shows the parameters of the hygroscopic equilibrium models, the coefficient of determination $\left(\mathrm{R}^{2}\right)$, values of relative mean error $(\mathrm{P})$, estimated mean error (SE) and the Chi-square test $\left(\chi^{2}\right)$, for 'cajuzinho-do-cerrado' achenes obtained by desorption, at different temperatures.

The coefficient of determination for the models of ChungPfost, Copace, Modified Halsey, Sigma Copace, Cavalcanti Mata, Modified Henderson, Henderson, Oswin and Modified GAB showed values higher than $95 \%$, which are adequate for the acceptable representation of the studied phenomenon (Madamba et al., 1996). 
Table 1. Mean values of equilibrium moisture content (\% d.b.) of achenes of 'cajuzinho-do-cerrado' (Anacardium humile St. Hil.) obtained by the process of desorption under different conditions of temperature $\left({ }^{\circ} \mathrm{C}\right)$ and water activity (decimal)

\begin{tabular}{ccccc}
\hline Water activity & \multicolumn{4}{c}{ Temperature $\left({ }^{\circ} \mathrm{C}\right)$} \\
\cline { 2 - 5 } (decimal) & $\mathbf{1 0}$ & $\mathbf{2 0}$ & $\mathbf{3 0}$ & $\mathbf{4 0}$ \\
0.306 & - & - & 4.51 & - \\
0.309 & - & 4.52 & - & - \\
0.335 & - & 5.26 & - & - \\
0.340 & - & - & 5.47 & - \\
0.419 & - & - & - & 5.28 \\
0.470 & - & - & - & 6.10 \\
0.642 & - & - & 9.83 & - \\
0.644 & 9.74 & - & - & - \\
0.653 & - & 9.63 & - & - \\
0.700 & 10.79 & - & - & - \\
0.715 & - & - & - & 9.63 \\
0.736 & - & 13.40 & - & - \\
0.779 & - & - & 12.39 & - \\
0.816 & - & - & 13.37 & - \\
\hline & & & & \\
\hline
\end{tabular}

For the values of relative mean error, the Copace model showed the lowest value (4.74\%) and the BET model showed the highest value (10.70). The other models showed acceptable magnitudes for the selection, according to Mohapatra \& Rao (2005), who point out that values of relative mean error lower than $10 \%$ are recommended for the selection.

The Copace model showed the best result for the estimated mean error and for the Chi-square test, the lowest one among the tested models, which corroborates the results of Günhan et al. (2005), who claimed that the lower the Chi-square value, the better is the fit of the model.

The models of Copace, Modified Halsey, Oswin and Modified GAB showed significant coefficients at 1 and $5 \%$ by the t-test; thus, the Copace model showed the best values for the fit to the experimental data, evidencing the lowest values for the relative and estimated mean errors and the Chi-square test, besides the highest value for the coefficient of determination. Therefore, this model was selected to represent the hygroscopicity of 'cajuzinho-do-cerrado' achenes.

All the tested models were satisfactory for the studied species, except the BET. The Oswin model can be used to obtain the hygroscopic equilibrium of the seeds of Anadenanthera peregrina (L.) Speng ('angico') (Borges et al., 2009). The models of Modified Henderson and Chung-Pfost are the ones that best represented the hygroscopicity of cotton seeds (Gossypium hirsutum L. r. latifolium Hutch), with and without linter (Oliveira et al., 2013). Caetano et al. (2012), working with Anacardium othonianum, observed that the model of ChungPfost showed the best fit to the experimental data, which is also the one that best fitted to the data of 'cajuzinho-do-cerrado' .

The values of equilibrium moisture contents of 'cajuzinhodo-cerrado' achenes, obtained through desorption, and their isotherms estimated by the Copace model are shown in Figure 1.

As the moisture content increases, there is an increment in water activity at constant temperature, and the desorption isotherm curves can be considered as Type III, i.e., they show an exponential behavior. Additionally, the model has limitations to predict the moisture contents when the relative humidity becomes close to zero, as reported by Botelho (2012).

As for 'cajuzinho-do-cerrado' and also for Raphanus sativus L. (forage radish), tested by Sousa et al. (2013), and fruits of Crambe abyssinica (crambe), analyzed by Costa et al. (2013), the Copace model was the most adequate for the representation of the desorption process of these species. Thus, according to the behavior of the desorption isotherms for 'cajuzinho-docerrado' achenes, in general, the composition of the product (solutes) has little affinity to water molecules. This fact is justifiable, because the product is preferentially composed of lipids and carbohydrates (Pena et al., 2010).

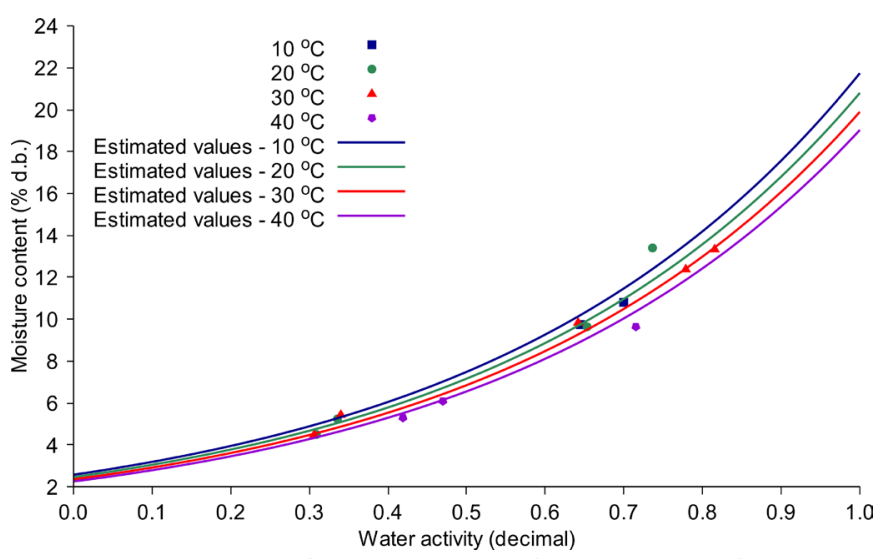

Figure 1. Water desorption isotherms for achenes of 'cajuzinho-do-cerrado' (Anacardium humile St. Hil.), estimated by the Copace model for different conditions of temperature and water activity

Table 2. Parameters of the hygroscopic equilibrium models for the achenes of 'cajuzinho-do-cerrado' (Anacardium humile St. Hil.) with their respective coefficients of determination $\left(\mathrm{R}^{2}\right)$, relative $(\mathrm{P}, \%)$ and estimated mean errors $(\mathrm{SE}$, decimal), Chi-square test ( $\chi^{2}$, decimal) and coefficients of the fitted models $(a, b$ and $c)$

\begin{tabular}{|c|c|c|c|c|c|c|c|}
\hline \multirow{2}{*}{ Models } & \multirow{2}{*}{$\mathbf{R}^{2}$} & \multirow{2}{*}{$\begin{array}{l}\mathbf{P} \\
\%\end{array}$} & SE & $\chi^{2}$ & \multicolumn{3}{|c|}{ Coefficients } \\
\hline & & & \multicolumn{2}{|c|}{ decimal } & $a$ & b & C \\
\hline Chung-Pfost & 0.9636 & 5.19 & 0.684 & 0.468 & $30.4676^{\star \star}$ & $5.1415^{\star \star}$ & $105.7053^{\text {ns }}$ \\
\hline Copace & 0.9680 & 4.74 & 0.642 & 0.412 & $0.9930^{* *}$ & $0.0044^{*}$ & $2.1307^{\star *}$ \\
\hline $\mathrm{GAB}$ & 0.9499 & 5.78 & 0.803 & 0.644 & $6.5008^{*}$ & $4.0711^{\mathrm{ns}}$ & 0.7270 ** \\
\hline Modified Halsey & 0.9600 & 5.52 & 0.717 & 0.514 & $3.0595^{* *}$ & $0.0100^{*}$ & $1.6415^{\star \star}$ \\
\hline Sabbah & 0.9453 & 7.67 & 0.839 & 0.703 & $19.1489 * \star$ & $1.1461^{\star *}$ & $0.0490^{\text {ns }}$ \\
\hline Sigma Copace & 0.9672 & 5.01 & 0.649 & 0.422 & $0.1044^{\text {ns }}$ & $0.0052^{*}$ & 1.1840 ** \\
\hline Cavalcanti Mata & 0.9596 & 5.53 & 0.721 & 0.520 & $-0.0336^{\star}$ & $0.1016^{\text {ns }}$ & 1.3750 ** \\
\hline Modified Henderson & 0.9652 & 5.19 & 0.669 & 0.447 & $0.0003^{\text {ns }}$ & $146.2516^{\text {ns }}$ & $1.3770^{\star \star}$ \\
\hline Henderson & 0.9624 & 5.29 & 0.666 & 0.444 & $0.00016^{* *}$ & $1.3698^{* \star}$ & - \\
\hline BET & 0.8435 & 10.70 & 1.358 & 1.845 & $136.7409^{\star \star}$ & $0.3329 * \star$ & - \\
\hline Oswin & 0.9669 & 4.74 & 0.652 & 0.426 & $8.0407^{\star \star}$ & $-0.0396^{\star}$ & $-2.1083^{\star \star}$ \\
\hline Modified GAB & 0.9633 & 5.07 & 0.687 & 0.472 & $5.1618^{* *}$ & $0.8023^{* *}$ & $176.5983^{* *}$ \\
\hline
\end{tabular}

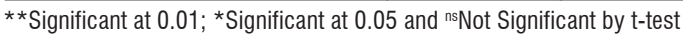


The values of integral isosteric heat of desorption $\left(Q_{\mathrm{st}}\right)$ as a function of the equilibrium moisture content ( $\%$ d.b.) are shown in Figure 2.

The isosteric heat of desorption of 'cajuzinho-do-cerrado' achenes decreased with the increment in moisture content (4.51 to $13.40 \%$ d.b.), showing that there is an increase in the energy necessary to remove water from the achenes, with magnitudes of the isosteric heat ranging from 2734.82 to $2548.49 \mathrm{~kJ} \mathrm{~kg}^{-1}$. These values corroborate those found by Corrêa et al. (2005a), for wheat grains with moisture content of 12 to $19 \%$ d.b., which ranged from 3735 to $2683 \mathrm{~kJ} \mathrm{~kg}^{-1}$. The same was observed for cowpea grains with moisture content of 4 to $16 \%$, which showed values of approximately 3361 to $2472 \mathrm{~kJ} \mathrm{~kg}^{-1}$ (Ayranci \& Duman, 2005). Wang \& Brennan (1991) explain that, in products with low moisture contents, the binding forces of the surface of the adsorbent substance with the water are higher.

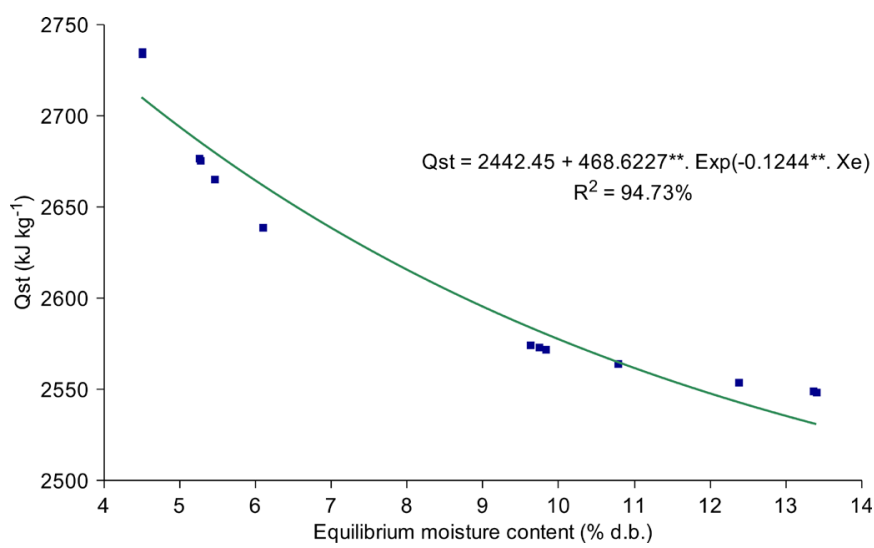

Figure 2. Integral isosteric heat of desorption for the achenes of 'cajuzinho-do-cerrado' (Anacardium humile St. Hil.) as a function of the equilibrium moisture content

\section{Conclusions}

1. The equilibrium moisture content of 'cajuzinho-docerrado' achenes at constant temperature increases with the increment in water activity.

2. All the tested models are adequate for this species, except the BET; the Copace model was selected to represent the desorption isotherms of 'cajuzinho-do-cerrado' achenes.

3. The values of integral isosteric heat of desorption of 'cajuzinho-do-cerrado' achenes for the moisture content range from 4.51 to 13.40 (\% d.b.) varied from 2734.82 to $2548.49 \mathrm{~kJ} \mathrm{~kg}^{-1}$, but increased with the reduction in moisture content.

\section{Acknowledgments}

To the Goiás Research Foundation (FAPEG), for the project funded by the Edict n. 005/2012, entitled: “Criopreservação e manutenção de bancos de germoplasmas in vivo de espécies nativas do Cerrado com potencial frutífero e medicinal"; to the direction of the Emas National Park, for authorizing the collection of 'cajuzinho-do-cerrado' fruits; to the Coordination for the Improvement of Higher Education Personnel (CAPES), for granting the Master's scholarship; to the National Council for Scientific and Technological Development (CNPq); to the Funding Authority for Studies and Projects (FINEP) and the Instituto Federal Goiano - Campus Rio Verde.

\section{Literature Cited}

Ayranci, E.; Duman, O. Moisture sorption isotherms of cowpea (Vigna unguiculata L. Walp) and its protein isotate at 10,20 and $30^{\circ} \mathrm{C}$. Journal of Food Engineering, v.70, p.83-91, 2005. http://dx.doi. org/10.1016/j.jfoodeng.2004.08.044

Borges, S.; Borges, E. E. L.; Correa, P. C.; Brune, A. Equilíbrio higroscópico e viabilidade de sementes de angico-vermelho (Anadenanthera peregrina (L.) Speng) em diferentes condições ambientais de armazenamento. Scientia Florestalis, v.37, p.475481, 2009.

Botelho, F. M. Cinética de secagem, propriedades físicas e higroscópicas dos frutos e caracterização do processo de torrefação dos grãos de Coffea canephora. Viçosa: UFV, 2012. 129p. Tese Doutorado

Brasil. Ministério da Agricultura, Pecuária e Abastecimento. Secretaria de Defesa Agropecuária. Regras para análise de sementes. MAPA/ ACS, 2009. 399p.

Caetano, G. S.; Sousa, K. A.; Resende, O.; Sales, J. F.; Costa, L. M. Higroscopicidade de sementes de caju-de-árvore-do-cerrado. Pesquisa Agropecuária Tropical, v.42, p.437-445, 2012. http:// dx.doi.org/10.1590/S1983-40632012000400012

Corrêa, P. C.; Goneli, A. L. D.; Resende, O.; Ribeiro, D. M. Obtenção e modelagem das isotermas de dessorção e do calor isostérico de dessorção para grãos de trigo. Revista Brasileira de Produtos Agroindustriais, v.7, p.39-48, 2005a. http://dx.doi. org/10.15871/1517-8595/rbpa.v7n1p39-48

Corrêa, P. C.; Resende, O.; Ribeiro, D. M. Isotermas de sorção das espigas de milho: Obtenção e modelagem. Revista Brasileira de Milho e Sorgo, v.4, p.126-134, 2005b. http://dx.doi. org/10.18512/1980-6477/rbms.v4n1p126-134

Costa, L. M.; Resende, O.; Oliveira, D. E. C. Isotermas de dessorção e calor isostérico dos frutos de crambe. Revista Brasileira de Engenharia Agrícola e Ambiental, v.17, p.412-418, 2013. http:// dx.doi.org/10.1590/S1415-43662013000400009

Günhan, T.; Demir, V.; Hancioglu, E.; Hepbasli, A. Mathematical modelling of drying of bay leaves. Energy Conversion and Management, v.46, p.1667-1679, 2005. http://dx.doi.org/10.1016/j. enconman.2004.10.001

Iglesias, H.; Chirife, J. Isosteric heats of water vapour sorption on dehydrated foods. Part II: Hysteresis and heat of sorption comparison with BET theory. Lebensmittel Wissenschaft and Technologie, v.9, p.123-127, 1976.

Lima, E. E. da; Silva, A. S.; Figueirêdo, R. M. F. de; Queiroz, A. J. de M. Estudo das isotermas e calor isostérico de adsorção da farinha da coroa de frade. Revista Brasileira de Produtos Agroindustriais, v.10, p.163-170, 2008. http://dx.doi.org/10.15871/1517-8595/rbpa. v10n2p163-170

Madamba, P. S.; Driscoll, R. H.; Buckele, K. A. The thin-layer drying characteristics of garlic slices. Journal of Food Engineering, v.29, p.75-97, 1996. http://dx.doi.org/10.1016/0260-8774(95)00062-3 Marcos Filho, J. Fisiologia de sementes de plantas cultivadas. Piracicaba: FEALQ, 2005. 495p.

Mohapatra, D.; Rao, P. S. A thin layer drying model of parboiled wheat. Journal of Food Engineering, v.66, p.513-518, 2005. http://dx.doi. org/10.1016/j.jfoodeng.2004.04.023 
Oliveira, D. E. C.; Resende, O.; Smaniotto, T. A. S.; Campos, R. C. Isotermas e calor isostérico das sementes de algodão com línter e sem línter. Revista Brasileira de Produtos Agroindustriais, v.15, p.283-292, 2013. http://dx.doi.org/10.15871/1517-8595/rbpa. v15n3p283-292

Pena, R. S.; Mendonça, N. B.; Almeida, M. D. C. Comportamento higroscópico do açaí em pó. Revista Brasileira de Produtos Agroindustriais, v.12, p.153-161, 2010. http://dx.doi. org/10.15871/1517-8595/rbpa.v12n2p153-161

Silva, F.; Park, K. J.; Magalhães, P. M. Isotermas de dessorção de Calendula officinalis L.: Determinação experimental e modelagem matemática. Revista Brasileira Plantas Medicinais, v.9, p.21-28, 2007.
Sousa, K. A.; Resende, O.; Costa, L. M. Isotermas de dessorção das sementes de nabo forrageiro obtidas pelos métodos dinâmico e estático. Revista Brasileira de Engenharia Agrícola e Ambiental, v.17, p.216-222, 2013. http://dx.doi.org/10.1590/S141543662013000200013

Tocon, R. V.; Baroni, A. F.; Brabet, C.; Gibert, O.; Pallet, D.; Hubinger, M. D. Water sorption and glass transition temperature of spray dried açaí (Euterpe oleracea Mart.) juice. Journal of Food Engineering, v.94, p.215-221, 2009. http://dx.doi.org/10.1016/j. jfoodeng.2009.03.009

Wang, N.; Brennan, J. G. Moisture sorption isotherm characteristics of potato at four temperatures. Journal of Food Engineering, v.14, p.269-287, 1991. http://dx.doi.org/10.1016/0260-8774(91)90018-N 